\title{
Senegalese artisanal fishers in the apprehension of changes of the marine environment: A universal knowledge?
}

\author{
Adama Mbaye $^{\text {a,b, *, }}$ Marie-Christine Cormier-Salem ${ }^{\mathrm{b}}$, Jörn O. Schmidt ${ }^{\mathrm{e}, \mathrm{f}}$, Patrice Brehmer ${ }^{\mathrm{c}, \mathrm{d}}$ \\ ${ }^{a}$ Institut Sénégalais de Recherche Agricole, ISRA, Centre de Recherche Océanographique de Dakar-Thiaroye, CRODT, BP 2241, Centre PRH, Dakar, Senegal \\ b UMR PALOC IRD/MNHN, Sorbonne Université, CP 026, 57 Rue Cuvier 75231, Paris, Cedex 05, France \\ ${ }^{\mathrm{c}}$ IRD, Univ Brest, CNRS, Ifremer, Lemar, BP70, 29280, Plouzané, France \\ ${ }^{\mathrm{d}}$ Commission Sous Régionale des Pêches, CSRP, SRFC, Dakar, Senegal \\ e Center for Ocean and Society, Christian-Albrechts-Universität zu Kiel, Germany \\ ${ }^{\mathrm{f}}$ International Council for the Exploration of the Sea, Copenhagen, Denmark
}

\section{A R T I C L E I N F O}

\section{Keywords:}

Mode of apprehension

Local knowledge

Marine environment

Small scale fisheries

West africa

\begin{abstract}
A B S T R A C T
In the context of climate change, which accentuates the growing scarcity of fishery resources, young fishermen are exploring increasingly remote fishing grounds with the immediate consequence of numerous cases of accidents and disappearances at sea and many human and material losses. Faced with this situation of looking for solutions to prevent accidents, the traditional knowledge of West African fishermen was examined. Semistructured interviews and focus group meetings with fishermen aged 50 years or older were used to explore ways of understanding and predicting changes in the marine environment. It shows that experienced fishermen can apprehend the sea state, the occurrence of wind or precipitation, or orient themselves and understand the nature of fishing grounds and species through the stars, swell, waves, water table, animals, trees, clouds, sky colour, dugout, fish. The understanding, interpretation and, subsequently, the meaning they develop from their observations are based on empirical knowledge that can be tested and confirmed in other parts of the world. In this sense, the ways in which fishermen understand changes in the marine environment can be considered universal knowledge. Such knowledge, when properly transcribed, can be useful for conventional marine research and the prevention of accidents at sea, especially for the new generation of fishermen who rely solely on new technologies.
\end{abstract}

\section{Introduction}

\subsection{Background}

The context of climate change, marked by the high occurrence of extreme weather events, including bad weather at sea, exposes artisanal fishermen to a greater risk of accidents at sea. The scarcity of fishery resources, which pushes fishermen to explore increasingly remote fishing areas, has, as immediate consequence, many cases of accidents and disappearances at sea with many human and material losses (Table 1).

The Senegalese counted 140 human casualties or missing in 2017, a more than twice increase (63\%) compared to 2016. Material losses are estimated at one hundred and forty million eighty thousand five hundred $(140,080,500)$ XOF (MPEM/DPM, 2018). Thus, the control of the adverse effects of the climate has become one of the challenges for the socio-economic development of the fisheries sector in Senegal (FIDA, 2016).

The mouth of the Senegal River alone recorded between 2003 and 2019, 422 accidents for 352 fishermen reported missing and the average age of the reported disappeared is 21 years.

Despite numerous initiatives to reduce these accidents, such as the establishment of an early warning system to provide fishermen with real-time information on weather forecasts and extreme marine phenomena (e.g. high swells, strong winds, fog, storms), accidents at sea still increase (USAID, 2018). The fisheries administration considers that the main causes of these accidents are non-compliance with meteorological instructions and the overloading of fisherman canoes (MPEM/DPM, 2018). However, others consider the main cause as the lack of

\footnotetext{
* Corresponding author. Institut Sénégalais de Recherche Agricole (ISRA), Centre de Recherche Océanographique Dakar-Thiaroye (CRODT), BP 2241, Centre PRH, Dakar, Senegal.

E-mail address: ambayeskr@yahoo.fr (A. Mbaye).
} 
Table 1

Assessment of accidents and loss of life at the mouth of the Senegal River from 2003 to 2019.

\begin{tabular}{lll}
\hline Years & Number of accidents & Fishermen reported missing \\
\hline 2003 & 19 & 11 \\
2004 & 30 & 15 \\
2005 & 11 & 25 \\
2006 & 30 & 30 \\
2007 & 27 & 18 \\
2008 & 10 & 10 \\
2009 & 38 & 38 \\
2010 & 12 & 11 \\
2011 & 09 & 16 \\
2012 & 93 & 11 \\
2013 & 20 & 32 \\
2014 & 02 & 06 \\
2015 & 17 & 27 \\
2016 & 21 & 25 \\
2017 & 38 & 52 \\
2018 & 42 & 56 \\
2019 & 54 & 55 \\
General Total & 422 accidents & 352 fishermen reported missing \\
\hline
\end{tabular}

Source: Fisheries Control and Surveillance Service of Saint-Louis 2020.

experience of the younger fishermen generation, characterised mainly by lack of control or the loss of the ecological knowledge and practices of old fishermen that were traditional systems for preventing risks at sea (Mbaye, 2018, p. 336; Nakashima and Roué, 2002; Roué et al., 2017).

In this context, the revival and application of local or traditional ecological knowledge and practices can support ongoing efforts to increase the resilience of fishers (Ruddle, 1994, p. 114; Smit et al., 2000). This work sheds light on traditional knowledge and practices related to preventive measures and response mechanisms aimed at mitigating accidents related to fishing activity.

\subsection{Theoretical and conceptual framework}

Marine resources and the marine environment, which are major challenges for development policies, have been the subject of numerous reflections by scientists and public authorities for several decades (Nursey-Bray et al., 2016; Tengö et al., 2017). Admittedly, with the participatory approach advocated since the 1990s, it is increasingly recognized that the empirical knowledge and practices of coastal communities acquired through experience and transmitted orally from generation to generation can play a significant role in management policies. (Berkes et al., 1995, 2000; Dahl, 1989; Mbaye et al., 2017; Satia and Horemans, 1995, p. 103). However, it is noted that the scope and effects of the fisheries management measures put in place are more concerned with the long-term conservation and sustainable use of fisheries resources (Davis et al., 2004; Grant and Berkes, 2007; Davis and Ruddle, 2010, 2012; Deb 2015; Berkes, 2015, p. 394; Mbaye et al., 2017) than with the protection of the fishermen, who exploit this resource (FAO, 2004, pp. 1020-1459). As a result, the formulation and implementation of policies in terms of safety at sea for fishers remains in the domain of technicians and focuses more on aspects of logistics and meteorological data. On the other hand, the knowledge of fishers regarding their safety at sea system is little taken into account (FIDA, 2016; Remolà \& Gudmundsson, 2018).

Nevertheless, given the various successes of local ecological knowledge in resource management and conservation (Berkes, 1998), it is increasingly recognized that this traditional ecological knowledge of fishers can also play a role in solving security problems, including those related to climate variability and change (Remolà \& Gudmundsson, 2018).

Groups of fishermen share a body of knowledge that allows them to predict or interpret variations in climatic parameters (Mbaye, 2018, p. 336). Similarly, they can interpret the presence or absence of fish species from a "reading of the marine environment" by comparing their knowledge of the bio-ecology of species and their knowledge of changes in marine and estuarine ecosystems (Barthélémy, 2005; Le Fur et al., 2011).

However, although some knowledge is intelligible and can be confronted with scientific results, fishers' knowledge is still considered localized (Johannes, Freeman, \& Hamilton, 2008; Deepananda et al., 2015; Gunawardena, Jutagate, \& Amarasinghe, 2016), group-specific, referring to religious syncretism to the supernatural and therefore not universal (Berkes et al., 2008; Agossou, 2008).

This perception of fishermen's knowledge has led to numerous debates on the value and consideration that both parties give them in adaptation strategies. Thus, at a time when traditional knowledge is the subject of great interest (Berkes et al., 2008), some still doubt its effectiveness in adaptation strategies (Angelini, 2012, p. 102).

It is based on observation that although Senegalese fishing communities have not had measuring instruments; they have nevertheless developed their observations of atmospheric phenomena, established empirical relations of cause and effect, and accumulated knowledge over a long period of time on certain natural phenomena (Mbaye, 2019). It is these phenomena that enable them to tell or predict the weather that it is or will be according to the physical aspect of meteorological elements (temperature, wind, swell, rain), the apparent movement of the stars, the behavior of trees or animals (marine or terrestrial), the taste, color or shape of certain elements in their environment. Thus, the ways in which artisanal fishermen understand changes in marine environmental parameters reflect their knowledge of fishing and its environment. Designated under several terms such as "empirical", "local", "traditional", "endogenous", "indigenous", "vernacular", "native" or "popular", the knowledge thus named is considered to be localized, referring to knowledge that is as much theoretical, symbolic as it is practical and therefore considered to be non-scientific; that is to say, non-systematic, non-objective, non-standardized and non-formalized (Rondeau, 2016).

The World Intellectual Property Organization (WIPO), distinguishes between "indigenous knowledge" held and used by a population that considers itself indigenous and traditional knowledge, owned by members of a distinct culture" Thus, the WIPO states that "Indigenous knowledge fits squarely within the category of traditional knowledge, whereas traditional knowledge is not necessarily indigenous" (WIPO/CIPI, 2002, p 18).

For United Nations Educational, Scientific and Cultural Organization (UNESCO, 2003), local knowledge refers to the cumulative and complex sets of knowledge, know-how, practices and representations that are perpetuated and developed by people with a long history of interaction with their natural environment. The Food and Agriculture Organization of the United Nations (FAO, 2005, p. 135) defines local knowledge as a set of facts related to the system of concepts, beliefs and perceptions that people draw from the world around them. This definition is in line with that of Warren (1993) and Hountondji (1994), who argue that local knowledge represents the body of knowledge acquired by a local population through the accumulation of experiences and the interpretation of the environment in a given culture. It represents the reflection of agro-ecological and socio-economic factors embedded in cultural preferences and traditions. Warren (1993) adds that local knowledge includes ideas, experiences, practices and information that have either been generated locally or produced outside the community, but which have been transformed by local people and incorporated over time into local agro-ecological and socio-economic cultural conditions. Warren's definition thus has the advantage of taking into account foreign knowledge that may become incorporated into local knowledge over time. Similarly, knowledge held by one community or group of fishers may be appropriated by other communities.

Briggs and Sharp (2004) point out that local knowledge, like all other types of knowledge (scientific, technical, etc.), is dynamic in nature. It is therefore an accumulation of knowledge that essentially aims to react to the modification of environmental conditions often caused by changes in ecological and human parameters. 
Berkes et al. (2008) acknowledges the ambiguity of his definition of local ecological knowledge and expresses one of the reservations about the word "traditional", because according to him, "tradition" is static whereas "local" and "indigenous" knowledge systems are often dynamic and adapted to meet contemporary needs. They see them as a cultural tool transmitted as a "knowledge-practice-belief complex" (Berkes et al., 2008), which mainly concerns the relationships between living beings, including humans.

Regarding the scope of this so-called knowledge, Varela (2004) argues that these types of knowledge conveyed by fishers refer to something that resembles knowledge, but which would not have a very advanced level of formalization. It would be experiential knowledge, that is to say, knowledge acquired through experience, therefore less universal, more local, and more specific, transmitted by imitation.

For his part, Lévy-Leblond (2006) qualifies this knowledge as "protoscientific" to say that it is "knowledge that is certainly effective and "objectifiable" (in relation to an external reality)", but not autonomous, that is to say that it remains "intrinsically linked to this or that technical, economic, mythical or playful activity”. Rondeau (2009, pp. 289-295) specifies that "protoscientific knowledge is not very far from so-called scientific knowledge. It closely precedes it - even prepares it - in all human societies and at all times" (Rondeau, 2009, pp. 289-295).

Dahan (2001) argues that considering these types of knowledge as sources, that have fed the great and unique river of science, too often leads to "finally underestimating its specific historicity". She points out that local knowledge has its own characteristics, both epistemological and sociological, which in no way allow it to be considered as a mere tributary of the great river of science. Whether these interpretations and meanings are qualified as "protoscientific", the fact remains that their validity can be assessed on the basis of their operationality and the accuracy of the information obtained.

It is therefore clear that the status of fishermen's knowledge depends on a definition of knowledge established from precise criteria that are based on a certain vision of what is called "science". This exclusive vision of science obscures certain types of fishermen's knowledge whose usefulness and application can be universal. It therefore seems essential to us to distinguish, among the knowledge of fishermen, that which can be verified (by deductions or hypotheses) and that which emanates from values and norms (Seijger et al., 2013).

The meaning of our article is to valorize the heritage of specialized knowledge of Senegalese artisanal fishermen which can be subjected to verification so that they are recognized and used universally in the apprehension of changes in environmental parameters and the prevention of risks. We mean here by universal knowledge, the modes of apprehension of the marine environment by the Senegalese fishermen artisans that we can verify, find or apply in other communities of fishermen everywhere in the world.

\section{Materials and methods}

Data were collected from fishermen from the Guet-Ndarien community, one of the largest fishing communities in Senegal (Charles-Dominique \& Mbaye, 2000). The fishermen of this community are present all along the coast of Senegal and are therefore familiar with the different marine and estuarine ecosystems. They also have the advantage of practicing almost all fishing techniques and are the only ones to devote themselves solely to fishing from their beginnings in the district of Guet-Ndar, from which they derive their name.

We favored the qualitative approach and opted for semi-structured individual and group interviews (Negura, 2006). This approach led us first to carry out an exploratory survey of the Guet-ndarien community, which allowed us to identify old fishermen at least 70 years old who were recognized as having a good experience in understanding the parameters of the marine environment and the signals announcing their disturbance. Individual interviews were conducted with these individuals. Stories were told about the maritime life of these experienced fishermen, which helped to delve into the history and traditions of fishing.

Group interviews were then conducted with fishermen aged 50 and over. These fishermen were selected according to the techniques practiced (anglers, net fishermen) and their fishing experience in other localities in Senegal and beyond the Senegalese Exclusive Economic Zone (EEZ). The size of the group was between six and eight people. These group interviews made it possible to cross-check the knowledge of the different categories with each other and with the knowledge of old fishermen.

The various individual and group interviews were carried out between 2015 and 2016 and involved at least 50 people, only men since there are no female fishers in the Guet-ndarien community. The interviews were conducted in Wolof, using a structured guide in French and translated into Wolof during the discussions. In addition to notetaking, the various interviews were recorded using an audio recorder and then transcribed into French in the laboratory by a professional investigator from the Oceanographic Research Center of Dakar Thiaroye (CRODT), Mr. Falilou Niang, who has more than 30 years of experience in the field and has a good command of the vocabulary of the various fishing communities.

\section{Results}

\subsection{Modes of apprehension of the sea state}

\subsubsection{The moon}

An important element for fishers on the Grande Côte (North sandy coast of Senegal characterised by a wave barrier) is the swell that challenge operations on sea, being specifically dangerous for the small canoes fishers predominantly use. Aware of this, the Guet-Ndarien fishers need to ensure they use all available knowledge to guarantee safe fishing. They observe and interpret the various elements of nature which surround them (e.g., rain, wind, current, tide) in order to predict most of weather phenomena, which affect their fishing operations.

One of the major elements is the moon, as it generally determines the movement of the sea. The fishers determine periods of spring tide (lokk in Wolof), antonym of neap tide and those of dead waters (ndeey in Wolof) in relation to the different phases of the moon. When the moon disappears between the twenty-seventh and twenty-ninth $\left(27^{\text {th }}\right.$ and $29^{\text {th }}$ ) day of the lunar month, it is a period of spring tide. The sea is agitated for three to four days before the neap tide period begins on the first day of the following month. Between the fifteenth and the seventeenth day of the month, there is again a period of strong waters and an agitation of the sea. Between the eighth and the twenty-sixth day, it is the period of neap tide and rough sea. On the twenty-seventh day of the month, it is still the period of strong waters (rag in Wolof) and sea agitated. Therefore, the sea is often agitated between the $15^{\text {th }}$ and $17^{\text {th }}$ day of the lunar month and between the $27^{\text {th }}$ and the $29^{\text {th }}$ day (Table 2).

Thus, the knowledge of the lunar cycle is needed in the interpretation of the state of the sea.

The experienced fishers can determine upcoming rough sea conditions and thus the time to stop fishing and return to land or even not going out in the first place.

\subsubsection{Swell and waves}

The assessment of sea state is not limited only to the moon but is also carried out through rigorous observation of swells and waves. Their look and behaviour gives fishers an idea of the state of the sea. The strength of the swell is assessed according to the wave impacts (total energy) on the beach. During periods, where the sea hits the beach with force, is gass in Wolof. As a result, much of the sand is washed away. This indicates that the sea will be very rough in one or two days. As for the waves, their strength is observed visually during the day through the oscillations (wañ in Wolof). At night, fishers listen to the noise they make when they land on the coast. These three names are clearly linked to the notion of 
Table 2

Prediction of the periods of sea state and tides according to the days of the lunar month.

\begin{tabular}{|c|c|c|c|c|}
\hline $\begin{array}{l}\text { Lunar } \\
\text { month } \\
\text { days }\end{array}$ & $\begin{array}{l}\text { "Water } \\
\text { behavior" }\end{array}$ & $\begin{array}{l}\text { Sea } \\
\text { state }\end{array}$ & $\begin{array}{l}\text { Low tide hours } \\
\text { (fer) }\end{array}$ & $\begin{array}{l}\text { High tide hours } \\
\text { (nass) }\end{array}$ \\
\hline $\begin{array}{r}1 \text { st to } \\
14 \text { th }\end{array}$ & $\begin{array}{c}\text { Dead waters } \\
\text { (Ndeey) }\end{array}$ & Smooth & $\begin{array}{l}\text { One in the } \\
\text { morning and one } \\
\text { in the evening }\end{array}$ & Middle of the day \\
\hline $\begin{array}{c}15 \text { th to } \\
17 \text { th }\end{array}$ & $\begin{array}{l}\text { Strong } \\
\text { waters } \\
(L o k k)\end{array}$ & Rough & Middle of the day & $\begin{array}{l}\text { One in the } \\
\text { morning and one } \\
\text { in the evening }\end{array}$ \\
\hline $\begin{array}{c}18 \text { th to } \\
26 \text { th }\end{array}$ & $\begin{array}{c}\text { Dead waters } \\
\text { (Ndeey) }\end{array}$ & Smooth & $\begin{array}{l}\text { One in the } \\
\text { morning and one } \\
\text { in the evening }\end{array}$ & Middle of the day \\
\hline $\begin{array}{c}27 \text { th to } \\
29 \text { th }\end{array}$ & $\begin{array}{l}\text { Strong } \\
\text { waters } \\
(L o k k)\end{array}$ & Rough & Middle of the day & $\begin{array}{l}\text { One in the } \\
\text { morning and one } \\
\text { in the evening }\end{array}$ \\
\hline
\end{tabular}

The explanation is that between the 27th and 29th of each lunar month, the moon exerts a strong attraction (i.e., high tidal coefficient) on the sea before it appears; this causes the sea to be agitated. This agitation decreases between the 2nd and 3rd day of the month (i.e. 2nd to 3rd days after the moon appears).

wave period and energy (Ruggiero, Holman, \& Beach, 2004). "If the spacing of two troughs was 30 min and this spacing is reduced considerably to 5 min at this time, we think that high tide is settling in. Also, we can see that the current we are currently observing at the shoreline was not there, it is because there is a swell coming. We can also know the state of the sea through the way the current pulls them, the children who swim or the canoes who come back from fishing". Affirms an old fisherman.

At sea, the current and swell energy is also observed through the mooring line or a rope immersed in the water. The way the force of the current drives the rope allows the fishers to have an idea of the direction but also of the intensity of the current.

"When the sea is calm, the rope holding the anchor is straight, but if you see this rope stretching, sometimes leading to the canoe, you should think that there is a swell underneath. If you take the opportunity to return as soon as you arrive, if the "diakaw" had not passed by, you see him settling in and the godlegone is gradually preparing to take shape". Supports another old fisherman.

Although some of these observations seem trivial, the combination of observations allows an experienced fisher to predict the conditions of the sea and to assess the risks of going to sea.

\subsubsection{Through the manifestations of the water table}

Water table behavior can be a good indicator for predicting sea state according to some fishers. For example, old fishers often sink their feet into the marine sand, just where the waves wash up. If the sand is compact and does not let their feet sink, they conclude that the sea will be calm all day long. On the other hand, if the foot sinks into the substrate, it means that there will be a strong current, for example, in a north-south direction. Such processes can be related to significant changes in grain size along the beach, which represent coarsening in the direction of net wave-driven transport (McCave, 1978), i.e. a morpho sedimentary elementary process.

"If the sea is about to be rough you see the crabs that were near the sea moving towards the mainland. They know where the slick is and they do not dig there. If you see them leaving their first holes to dig further up, expect the water to arrive where they have moved and soon after that a swell will follow." Explains a Yoff's Ndarian Guest, Alioune Fall.

Similarly, if sand on the beach shows funnels like the ones breathing crabs leave, fisher infers that the water level has been lifted and that there will be a bottom swell, even if it is not visible on the sea at this time. This bottom swell underneath is more dangerous for fishers. "It's this swell we're seeing these days in Yoff. If you go to the football field, you will see a part of the field that is dry and another part that is wet. During the coming dry season, if there is a swell, it will reach the limit of the wet part because this part which is now wet shows the beginning of the swell, the groundwater will reach this limit'. Supports a fisherman of Guet-Ndar based in Yoff.

Through this mode of assuming, an experienced fisher who is travelling in the hinterland, far from the beach, is able to tell if the sea is rough or not. He looks at the bottom of a well: if there are air bubbles coming out, it means that the sea is rough or will become rough. The explanation is that when the sea is rough, it pushes the water level, which in turn pushes back the air that forms bubbles that come out of the wells.

\subsubsection{Behavior of animals}

The state of the sea can also be assessed through the behavior of certain animals. When leaving for a fishing trip at sea, the fisher observes the cat's behavior. If the cat puts her right paw on her face, the fisher deducts that the weather will be windy, rainy or rough. The explanation is that the cat uses the left leg more frequently but never the right leg to wipe its face because the magnetic waves enter from left to right. Cats are among the animals most sensitive to this phenomenon of magnetism.

Their hair, as well as the feathers of the roosters, capture the magnetism. Cats and pigeons are the first to feel the magnetic information. According to their knowledge, the pigeon captures magnetism through its feathers and the smallest disturbance is felt in its body as if it had been thrown a stone at it. Therefore, before any disturbance on earth, it flies away. "If there is an earthquake coming, the pigeons would be the first to know about it and will fly away before it finds them on earth. Many other animals feel this phenomenon and prepare themselves accordingly only humans stay to wonder what is happening. Men are the fools and they think they are the most intelligent ". Supports this same fisherman of Guet-Ndar based in Yoff.

Similarly, it is argued that when the hen has gone to bed to lay or incubate her eggs, if she is a little bent over to one side, it is a sign that the sea is rough now. According to their explanations, when the sea is rough, it produces a kind of mist that rises, as if it were fog. It is this atmospheric humidity that increases that chickens feel and thus spread their feathers to cool their bodies.

Similarly, if at a certain time of the year it is noticed that the dogs' ears are shredded, old fishers deduce that a storm will most likely arrive and there will be deaths at sea.

3.1.4.1. Modes of wind apprehension. Old Guet-Ndarian fishers have several modes to understand wind disturbances in advance. This is how they often scan the sky before boarding. This scrupulous observation can be made with the help of clouds, some of whose shapes suggest a strong wind. Such approach has been done in science (Shenx and Kreins, 1969) and shown good correlation. It can also be done through the colour of the sky, whose coverage by a more or less brown layer, allows to conclude from the existence of dust or not. This phenomenon is well known in science (Prospero \& Carlson, 1970). The possibility of a wind can also be appreciated through stars such as stars and the moon, whose behavior or colour also allows fishers to detect a wind.

Some explain that at night, when a wind is forecast, the stars seem to be agitated with jerky movements. Sometimes it is a kind of thick fog that forms in the sky. When it is a moon period, winds are indicated by changes in colour. Thus, as soon as the moon turns a reddish colour that reflects bronze, experienced fishers know that the next day the sea will be shaken by a wind. If the fisher is already at sea, the behavior of the pirogue on the water will allow him to detect a possible wind. The same is true for fish that exhibit behaviors or signs that predict possible disturbance of the sea (Diop et al., 2010, p. 68).

"One day I was with old Y. Sène. It was ten o'clock and we were just starting to fish when a member of the team caught a badèche that caught 
his attention. He then asked for the fish to be given to him. He looked at it closely and noticed that half of his eye was red while the other half was blue. He automatically requested that the anchor be lifted to return. Not having understood, his "nephew" who was in charge of the "helm" protested strongly against this decision, which he had difficulty understanding. This is all the more so since 4 cans of fuel had been consumed before arriving in this fishing area. At the uncle's insistence, he weighed anchor and headed back. It was only after 2 hours of driving that a strong wind broke out on the high seas. Fortunately, we were near the coast and we were able to dock before she arrived. Once at the beach, he looked at us and said: you will never be good fishers because you cannot observe. The fish had a red eye because it felt that the sea would be disturbed". Affirms a fisherman.

At sea, some fishers have the ability to detect the arrival of a strong wind by the smell or freshness that precedes it (empiric skill), as this fisher tells us:

"One day I was at sea with A. N, a very great fisher. He really had a gift. On that day, the yaranka was abundant and fishing was quiet. Suddenly, he asked us to roll up the lines and put everything away. I replied that the fish were attacking the bait. He insisted. When we did, he started the engine and headed for shore. As we approached the shore, a kind of tornado broke out on the high seas. He looked at me and insulted me, saying to me: anyone who relies on you risks losing his life at sea. So I asked him how he could have known that a strong wind was about to blow. He replied that you could feel it. The incoming wind is always beaten by its smell. On that day, there were many accidents at sea and several fishers lost their lives." Says a fisherman.

Fishers also know how to distinguish a transient wind from a wind that carries serious disturbances, i.e., a strong wind or a light wind. If they find that the wind coming from the earth has a different meaning than the one coming from the sky, they deduce that this wind will not be strong. But if both winds blow in the same direction, they expect a storm. Fishers also have the power to apprehend the length of time a blowing wind will last. They often announce that wind disturbances do not last more than three days or, if exceptionally a wind exceeds three days, they are convinced that the wind will not stop until it has lasted seven days.

3.1.4.2. Modes of rainfall apprehension. Fishers have the ability to estimate the start of the rainy season by observing the behavior of the vegetation. The trees that are starting to waterlogged indicate the beginning of winter. Therefore, according to some elders, if they find that trees that had the dry trunk all through the dry season start to feel a kind of dew falling on their trunk, they conclude that within a month it will rain. At this moment too, the arrival of the first rains is noticeable on the leaves of some trees that had fallen and are beginning to grow again. They specify that if it is the baobab tree (Bombacaceae), not all sides will take leaves at the same time. It is on the side where the leaves start to come out that the first rain will arrive. It has been shown in science that the Baobab was among the most effective tree that control their water loss (Fenner, 1980).

During the rainy season, experienced fishers feel that a storm will come through the leaves of trees that begin to dry as if they were burned and if they have also black spots. Similarly, the end of rainfall is estimated by the appearance of certain insects such as locusts and dragonflies, the presence of which is considered by fishers as marking the end of wintering. That is a classic process of seasonal population dynamics for entomologist (Maiga, Lecoq, \& Kooyman, 2008).

3.1.4.3. Benchmarks for orientation at sea. Fishers have developed their orientation system to navigate at sea and to locate fishing areas from a variety of benchmark as: stars in sky, trees along the coast, waves direction and height, water colour, water depth, humidity, and wind character. Thus, from dusk to dawn, the fisher usually uses the stars to orient himself (Richardson, 1926). The stars are divided into two groups: those that allow the fisher to go to sea and those that allow him to return to land.

When the sky is not clear due to clouds and fishers cannot see the stars, they use wave and wind directions. If he has headed towards the mainland, the fisher pays attention to the humidity of the wind. He considers that, the closer he gets to the coast, the drier the wind becomes and vice versa. In other words, the wet winds come from the sea and the dry winds from the continental shelf. Wind direction is also an indicator of fishermen's orientation. Therefore, if they go to sea, they pay attention to the fact that the wind is blowing in both their ears. Thus, on the way back, if they notice that the wind is blowing in only one ear, they tell themselves that they have made a mistake and they adjust the direction accordingly.

During the day, orientation is based on objects or trees identified on land. Nowadays in Saint-Louis, fishers, in addition to the city's trees, used water towers, the governance building, telecommunication station antennas, etc. acting as coastal marks. Subsequently, they made extensive use of the filaos tape from the 1970s onwards (Van Chi Bonnardel, 1985). The technique consisted in superimposing or associating objects according to the location. Thus, one or more trees could be superimposed on each other or on a building or even an antenna (Sène, 1985). On the high seas, when the fisher cannot see these objects, he focuses on the sun and more precisely on the shade of the canoe. Similarly, the way the swell rises and the directions of the waves that in their experience are always heading towards the coast serve as their means of orientation. The Viking used the same approach at sea with sun and shadow (Berkes et al., 2008).

"On the high seas there are no waves, only the wave of the swell can guide you. If you are in the waters of Saint-Louis at sea, if you drive and notice that your canoe is leaning more to the right, tell yourself that you are going towards the coast. It is the waves that make the canoe lie on its right side, because if you are in Saint-Louis, when you go to sea, our left side is the west (i.e. offshore) and our right side is the east (i.e. towards the coast). The waves leave from the open sea towards the coast. Likewise, if at the beginning for fishing you are horizontal to the wave on your left side, you go to Kayar, if you return it is your right side that must be positioned there. But if you come back with your back to the wave, tell yourself that you've lost yourself' Supports a fisherman from Guet-Ndar based in Kayar.

Knowing how to orient yourself is essential for a fisher, ensuring his safety at sea, but also fuel consumption and the catch level.

3.1.4.4. Modes of understanding the nature of fishing grounds and species. The recognition of the nature of the sea bottom, on which fishers want to operate, is often done with a stick. It is sunk into the water and the fisher sticks his ear to it. Once over a rocky area, the stick makes a deafening noise. This noise disappears when it leaves the rock, indicating a sandy or muddy sandy area. The presence of certain bird species on fishing grounds may also be a source of information about the type of environment. According to some elders, there are species of seabirds they call $x a a$ in Wolof and others called $u u k$ in Wolof that live in rocks and feed only on fat. The presence of these seabirds on a fishing site indicates a rocky bottom sheltering oily fish. Fishers also recognize the presence of fish through the air bubbles that come out of the water. The size, number and frequency of bubbles can be used to identify the type of fish that emit them.

Fishers also have the ability to recognize the type of fish species that have taken the bait. If they are fish that do not have teeth, such as white grouper (Epinephelus aeneus), machoiron (Arius heudelotii) and sea bream (Diplodus bellottii), they swallow the bait. Alternatively, if they are toothed fish, such as blue-spotted snappers (Lutjanus rivulatus), striped snappers (Lutjanus kasmira), or mediterranean grouper (Epinephelus marginatus), they take the bait from the hook. 


\section{Discussion}

It appears from these results that, faced with the risks associated with their activity, artisanal fishermen have based their early warning system - the key to their survival on their ability to predict changes in various environmental parameters by observing events in the natural world around them and linking them together (Horowitz, 2015; Mbaye, 2019). The apprehension of the state of the sea and made from the moon which determines the periods of living waters and those of dead waters; the swell, the waves, the water table, the animals. As regards the imminence of a wind, fishermen apprehend it from the clouds, the color of the sky, the stars and the moon, some of whose shapes hint at a strong wind, or the existence of dust or not, or to leave. It is the same for the behavior of the dugout canoe and the fish. The imminence of a storm is apprehended through the leaves of the trees, which begin to dry as if they were burnt and if they have black spots. Fishermen have developed their orientation system to move around the sea and to locate fishing areas from the stars, trees, waves, the color of the sea water, the depth of the water, the humidity, the character of the wind.

The knowledge of the fishermen described here is a cumulative body of knowledge, know-how, practices and representations maintained and developed whose history merges with the marine environment and fishing activity. Knowing how to interpret the occurrence of a change in the marine environment based on certain signals, that Dounias (2009) defines as "being biotemporal markers", is the basis for making decisions regarding the different phases of fishing activity such as the opportune moment to go to sea, to deploy fishing gear or to weigh anchor. The capacity to perceive these temporal signals, and therefore the capacity to anticipate a change in the marine environment, constitutes a determining step in the qualification of the fisherman in the conduct of his fishing activity. The capacity to understand, interpret and predict from these signals composed of a corpus of stimuli - visual, olfactory, sound, tactile - emitted by nature, is part of a discursive body of knowledge, formalized in a theoretical mode, concerned with objectification and its communicability outside the cultural environment specific to a group of fishermen. We realize here that the knowledge we have just described transcends a culture or a community and is intended to be universal knowledge that can be appropriated by all (Cormier-Salem and Roussel, 2002).

Such knowledge has been described in other communities. In the villages of Tonga and Tuvalu in the Solomon Islands, traditional forecasting techniques are based on observations of the sea and lagoon (size, intensity and noise of waves, color and smell of water, and volume of algae deposited on the beach), the sky (type and color of clouds, particular appearance of the moon), and winds (FIDA, 2016). Similarly, in Rapu-Rapu in the Philippines as well as in Aceh in Indonesia, it has been established that a foul odor from the sea signifies the approach of a storm or typhoon (Budi, 2010). There are other key indicators, such as phenology (e.g. the abundance of particular fruits such as mango and breadfruit as a sign of strong wind or heavy precipitation, and a rise in the water table in taro plantations as an indication of a rising sea level), and the behavior of birds and other animals (e.g. albatrosses flying at low altitudes warn of bad weather, and animals seeking refuge on high ground warn of approaching tsunamis). In Raimea and Lau-Hata, Timor-Leste, leeches and caterpillars appeared before the storms. When banana leaves and branches of other trees fall to the ground in the absence of strong winds, people in Rapu-Rapu, Philippines, prepare for a thunderstorm or typhoon (Budi, 2010). Birds, usually migratory species, are also seen as important indicators of changing seasons and their duration, as well as the imminence of heavy rainfall, thunderstorms or drought in Raimea and Maluru-Beaço in Timor-Leste and Sayung and Lipang in Indonesia. In Perez and Rapu-Rapu in the Philippines, the behavior of various animals helps predict risk: rays repeatedly leaping out of the water in summer, the rapid movement of sea snakes, and coconut crabs heading towards the land or climbing trees are all warning signs of thunderstorms or typhoons. Communities have also developed ways to prevent, mitigate, adapt to, or prepare for these risks using local methods and materials. In anticipation of a storm, for example, local plants are used to strengthen houses, such as Suhay (bamboo stems) in the Philippines and Ai Tatan (used as wooden spikes to secure the roof) in Timor-Leste (Hiwasaki et al., 2014).

Deb (2015) identified among Hindu coastal fishers in Bangladesh eight factors that are taken into account in their traditional ecological knowledge system for fisheries decision making. These factors include water color, wind direction and current, lunar periodicity, sediments and topography, celestial navigation, birds and animals, mangroves and fishing sites. Grant and Berkes (2007) identified nine categories of knowledge, that are important for finding and catching large pelagic fish, including seasons, bait use, gear technology, weather conditions, fishing practices, fish habits and behavior, fish movements, "popular oceanography" (seabirds, seawater color, current), and fish stomach contents (Medeiros et al., 2018).

All this empirical knowledge, that we have just described from around the world and that comes from experience, does not need a great deal of theory for its validity and can be assessed in terms of the tangible results that it gives (Agrawal, 2004; Collignon, 2005; Thomas, 2018). It is up to "researchers" to see how to incorporate them into their models for predicting changes in the marine environment (Baelde, 2007; Lesage, 2012; Löfmarck et al., 2017).

It is therefore a question of making a clear distinction between knowledge, that comes from a locality but whose scope is global and purely local beliefs. For example, members of the Indian watch community may firmly believe that a fishing trip without disturbing the weather can only take place thanks to the goodwill of the genius of the village through a mystical practice combining talismans, prayer and incantations. In this sense, knowledge would be a justification for superstition and obscurantism in other communities (Mbaye, 2013). On the other hand, the knowledge described here as a means of preventing possible disruption of climate parameters based on practical experience can be verified on a global scale.

Much knowledge of this type remains little known or valued, which unfortunately leads to its marginalization and sometimes virtual disappearance (Mboa Nkoudou, 2015; Cardona et al., 2018). The desire to protect from oblivion or disappearance knowledge whose existence is more worthy of a long-term perspective is highly commendable. Especially if the knowledge in question here concerning the ways in which artisanal fishers understand the marine environment includes safe incentives to help fishing professionals, particularly the new generation of fishers turned towards new technologies, to prevent accidents at sea.

As scientists seek to improve the predictability of climate phenomena, there is a need to integrate anthropological and socioenvironmental data into the development of predictive models for climate change (Loury, 2012).

\section{Conclusion}

This study shows that the close relation between artisanal fishermen and their natural environment makes them agents of "measurement" and prediction of changes that can occur in this environment, particularly on climatic parameters. Being confronted with the impacts of these changes through their activities, they thus participate in the observation and monitoring of changes. The fishermen have long favored this empirical knowledge, consisting of a set of knowledge and reasoning that each of them uses to conduct their activities and cope with the vagaries of the climate.

The limitation of the study was that it only considered the Guetndarian fishermen and did not compare knowledge according to gender, fishing technique, age, etc. The study was limited to the Guetndarian fishermen. Nevertheless, its major contribution is to have shown that analyses of the knowledge of artisanal fishermen should no longer be limited to demonstrating their usefulness but also and above all to claiming their universal scope, to show that the knowledge of 
fishermen, like university knowledge, has a scope that goes beyond the local context and can be verified everywhere in all marine environments of the globe (Berkes et al., 2008). In this sense, it is knowledge that is universal in scope. Fishermen's knowledge, which is based on an intellectual construction based on long empirical experience (Berkes, 2015, p. 394), does not need to follow the same method as that of other academic or university sciences and its validity should not be evaluated according to the same criteria as this one (Collignon, 2005; Mbonda and Rondeau, 2015; Kovács et al., 2016).

In this sense, with the different types of science called differently experimental sciences, practical sciences, etc., it is necessary to return to the notion of ethnosciences developed in the 1950s by American ethnologists. Through this notion, they sought to recognize the value of thoughts qualified as indigenous, while affirming their scientific foundation by demonstrating that they are based on rigorous classifications, that they are rational and differ from Western thought only in their objectives (Foucault, 1966; Lévy-Strauss, 1962).

The different names given to the knowledge embodied by fishers simply mean that these types of knowledge have value and deserve to be recognized and preserved. Certainly, this phase has been important, but it is necessary to go beyond this justification of recognizing the knowledge of a community or group alongside the so-called "learned" or "academic" knowledge, to place it in a constant relationship between the local and the global (Gerrtz, 1986, p. 293).

\section{Declaration of competing interest}

The authors declare that they have no known competing financial interests or personal relationships that could have appeared to influence the work reported in this paper.

\section{Acknowledgements}

This work was supported by Preface project of the European Commission's Seventh Framework Program [Grant Agreement 603521], as well as the AWA project funded by IRD and the BMBF [01DG12073E]. We also thank and the staff of UMR Paloc, which welcomed the first author as PhD student under the supervision of the second author, as well as the World Bank for a travel grant to allow first author to make doctoral trips in France. We are extremely grateful to all interviewers and the fishers involved in this study, as well as Pr Noel Keenlyside and Dr Mahaut de Versaille (UiB, Norway) for their early encouragements.

\section{References}

Agossou, D. (2008). Perceptions, savoirs locaux et stratégies d'adaptation des producteurs des communes de Glazoué et de Savalou au Centre du Bénin aux changements climatiques. In Mémoire d'ingénieur agronome, 132p. FSA-UAC.

Agrawal, A. (2004). Indigenous and scientific knowledge: Some critical comments. Indigenous Knowledge and Development Monitor, 3(3), 1-9.

Angelini, A. (2012). La valorisation des connaissances empiriques des pêcheurs professionnels, Mémoire de Fin d'Etudes, Diplôme d'Ingénieur Agronome, Spécialisation Halieutique, Option Gestion des Pêches et des Écosystèmes Côtiers et Continentaux. Rennes: Agrocampus Ouest. https://halieutique.agrocampus-ouest.fr/memoires/2 01201.pdf.

Baelde, P. (2007). Using Fishers' knowledge goes beyond filling gaps in scientific knowledge: Analysis of Australian experiences. In N. Haggan, B. Neis, \& I. G. Baird (Eds.), Fishers' knowledge in fisheries science and management. Paris, France: UNESCO. pp. 381-399.

Barthélémy, C. (2005). Les savoirs locaux: Entre connaissances et reconnaissance. VertigO, 6(1). https://doi.org/10.4000/vertigo.2997. https://journals.openedition. org/vertigo/2997\# entries

Berkes, F. (1998). Indigenous knowledge and resource management systems in the Canadian subarctic. In F. Berkes, \& C. S. Folke (Eds.), Linking social and ecological systems: Management practices and social mechanisms for building resilience (pp. 98-128). Cambridge, New York, UK, USA: Cambridge University Press.

Berkes F., 2015, Coasts for people: Interdisciplinary approaches to coastal and marine resource management 1st ed. Paperback: pages, ISBN-10: 1138779814, ISBN-13: 978-1138779815.

Berkes, F., Bernáth, B., Blahó, M., Egri, A., Barta, A., \& Horváth, G. (2008). An alternative interpretation of the viking sundial artefact: An instrument to determine latitude and local noon. Proc R Soc A, 469, 20130021. https://doi.org/10.1098/rspa.2013.0021
Berkes, F., Colding, J., \& Folke, C. (2000). Redécouverte des connaissances écologiques traditionnelles en tant que gestion adaptative. Ecological Applications, 10(5), 1251-1262.

Berkes, F., Folke, C. S., \& Gadgil, M. (1995). Traditional ecological knowledge, biodiversity, resilience and sustainability. In C. Perrings, K. G. Maler, C. S. Folke, \& B.-O. Jansson (Eds.), Biodiversity conservation: Policy issues and options (pp. 281-299). Dordrecht, The Netherlands: Kluwer Academic Publishers.

Briggs, J., \& Sharp, J. (2004). Indigenous knowledge and development: A postcolonial caution. Third World Quarterly, 25(4), 661-676. https://doi.org/10.1080/ 01436590410001678915

Budi, U. P. (2010). The role of traditional knowledge in fisheries management: A study case of panglima laot (sea commander) in the Aceh province of Indonesia, 431. World Maritime University Dissertations. http://commons.wmu.se/all_dissertations/431.

Cardona, A., Lefèvre, A., et al.Simon, S. (2018). Les stations expérimentales comme lieux de production des savoirs agronomiques semi-confinés : Enquête dans deux stations INRA engagées dans l'agro-écologie. Revue d'anthropologie des connaissances, 12(2), 139-170. https://www.cairn.info/revue-anthropologie-des-connaissances-2018-2page-139.htm.

Charles-Dominique, E., \& Mbaye, A. (2000). Les usages de l'espace dans la pêche artisanale sénégalaise. In Pierre Chavance, Nicolas Bez, Didier Gascuel, \& Alain Biseau (Eds.), Les espaces de l'halieutique. 4eme Forum halieumétrique (pp. 371-385). Paris: IRD. Colloques et séminaires.

Collignon, B. (2005). Que sait-on des savoirs géographiques vernaculaires ? (What do we know about vernacular geographic knowledge). In Bulletin de l'Association de géographes français, 82e année, 2005-3 (septembre). La géographie économique au début du XXIe siècle: Agglomération et dispersion/géographie vernaculaire, sous la direction de Georges benko et béatrice Collignon (pp. 321-331). https://doi.org/10.3406/ bagf.2005.2467

Cormier-Salem, M.-C., Roussel, B., \& Martin, J.-Y. (2002). Patrimoines et savoirs naturalistes locaux. In Développement durable? doctrines, pratiques, evaluations (pp. 126-142). Paris: IRD Editions.

Dahan, A. (2001). La tension nécessaire. Entre universalité et localité des savoirs scientifiques. Alliage (en ligne). No.45-46 http://www.tribunes.com/tribune/alliage/45/Dah an_45.htm.

Dahl, A. L. (1989). Traditional environmental knowledge and resource management in New Caledonia. p. 57-66. In R. E. Johannes (Ed.), Traditional ecological knowledge: A collection of essays. Gland, Cambridge, Switzerland, UK: IUCN.

Davis, A., Hanson, J. M., Watts, H., \& MacPherson, H. (2004). Local ecological knowledge and marine fisheries research: The case of white hake (Urophycis tenuis) predation on juvenile American lobster (Homarus americanus). Canadian Journal of Fisheries and Aquatic Sciences, 61, 1191-1201.

Davis, A., \& Ruddle, K. (2010). Constructing confidence: Rational skepticism and systematic enquiry in local ecological knowledge research. Ecological Applications, $20,880-894$.

Davis, A., \& Ruddle, K. (2012). Massaging the misery: Recent approaches to fisheries governance and the betrayal of small-scale fisheries. Human Organization, 71, 244-254.

Deb, A. K. (2015). "Something sacred, something secret": Traditional ecological knowledge of the artisanal coastal Fishers of Bangladesh. Journal of Ethnobiology, 35 (3), 536-565.

Deepananda, K. H. M. A., \& Amarasinghe U.S. et Jayasinghe-Mudalige U.K.. (2015). Connaissances indigènes dans la pêche à la senne de plage au Sri Lanka : Un facteur indispensable dans la gestion communautaire des pêches. Politique maritime, 57, 69-77.

Diop, M., Diop, N., \& Diouf, B. L. (2010). Savoirs endogènes et changements climatiques. Enda Repao.

Dounias, E. (2009). The sentinel key role of indigenous peoples in the assessment of climate change effects on tropical forests. IOP Conference Series: Earth and Environmental Science, 6, 572008. https://doi.org/10.1088/1755-1307/6/57/ 572008

FAO. (2004). La sécurité en mer, élément essentiel de la gestion des pêche, FAO, Circulaire sur les pêches $N^{\circ} 966$ FIIT/C966 (Fr). ISSN.

FAO. (2005). Interaction du genre, de la biodiversité agricole et des savoirs locaux au service de sécurité alimentaire. Manuel de formation.

Fenner, M. (1980). The induction of a light requirements in Bidens pilosa seeds by leaf canopy shade. New Phytologist, 84, 103-106, 1980.

FIDA. (2016). L'avantage des savoirs traditionnels. Les savoirs des peuples autochtones dans les stratégies d'adaptation au changement climatique et d'atténuation de ses effets (pp. 1-60). Rome: FIDA. https://www.uncclearn.org/sites/default/files/inventor y/traditional_knowledge_advantage_f.pdf.

Foucault, M. (1966). Les Mots et les Choses (p. 404). Gallimard: Archéologie des sciences humaines.

Gerrtz, C. (1986). Savoir local, savoir global, les lieux du savoir, Paris, PUF, Traduction 1ère édition anglaise 1983. dernière réédition française, 2002.

Grant, S., \& Berkes, F. (2007). Fisher knowledge as expert system: A case from the longline fishery of Grenada, the eastern caribbean. Fisheries Research, 84(2), 162-170. https://doi.org/10.1016/j.fishres.2006.10.012

Gunawardena, N. D. P., Jutagate, T., \& Amarasinghe, U. S. (2016). Patterns of species composition of beach seine fisheries off North-Western coast of Sri Lanka, fishers' perceptions and implications for co-management. Marine Policy, 72, 131-138. https://doi.org/10.1016/j.marpol.2016.07.007

Hiwasaki, L., Luna, E., Syamsidik, \& Shawd, R. (2014). Process for integrating local and indigenous knowledge with science for hydro-meteorological disaster risk reduction and climate change adaptation in coastal and small island communities. International Journal of Disaster Risk Reduction, 10, 15-27 16. http://www.sciencedirect.com/sci ence/article/pii/S2212420914000612, 2014. 
Horowitz, L. S. (2015). Local environmental knowledge. In G. B. T. Perreault, \& J. McCarthy (Eds.), The Routledge handbook of political ecology (pp. 235-248). Abingdon, Oxon; New York: NY Routledge.

Hountondji, P. J. (1994). Les savoirs endogènes : Pistes pour une recherche. Paulin Hountondji. Dakar, CODESRIA, 1994, 356, 2-86978-039-7 (broché).

Johannes, R. E., Freeman, M. M. R., \& Hamilton, R. J. (2008). Ignore, Fishers' knowledge and miss the boat. Fish and Fisheries, 1(3), 257-271. https://doi.org/10.1111/j.14672979.2000.00019.x

Kovács, E. K., \& Pataki, G. (2016). The participation of experts and knowledges in the intergovernmental platform on biodiversity and ecosystem services (IPBES). Environmental Science \& Policy, 57, 131-139. https://doi.org/10.1016/j. envsci.2015.12.007

Le Fur, J., Guilavogui, A., \& Teitelbaum, A. (2011). Contribution of local fishermen to improving knowledge of the marine ecosystem and resources in the Republic of Guinea, West Africa, Can. Journal of Fisheries and Aquatic Science, 68, 1454-1469.

Lesage, L. (2012). Les connaissances traditionnelles et la science: Un mariage possible. $L e$ Naturaliste Canadien, 136, 5-10. https://www.usherbrooke.ca/environnement /fileadmin/sites/environnement/documents/Essais_2014/Pouliot_J_2014-09-18_. pdf.

Lévy-Lebond, J.-M. (2006). La science est-elle universelle?. Le Monde diplomatique (en ligne). Numéro de mai. http://www.monde-diplomatique.fr/2006/05/LEVY_LEBL OND/13453.

Lévy-Strauss, C. (1962). La pensée sauvage. In Pion, coll. "Presses pocket". Paris: Pion, 1992.

Löfmarck, E., \& Lidskog, R. (2017). Bumping against the boundary: IPBES and the knowledge divide. Environmental Science \& Policy, 69, 22-28.

Loury, E. (2012). Q\&A: What can indigenous people tell us about climate change? Sciencemag.org. http://news.sciencemag.org/2012/02/qa-what-canindigenous- pe ople-tell-us-about-climate-change.

Maiga, I. H., Lecoq, M., \& Kooyman, C. (2008). Ecology and management of the Senegalese grasshopper Oedaleus senegalensis (Krauss 1877) (Orthoptera: Acrididae) in West Africa: review and prospects. International Journal of Entomology, 44(3), 271-288. https://doi.org/10.1080/00379271.2008.10697563

Mbaye, A. (2013). Système de gestion des ressources et pluralité des règles. In André Fontana, \& Alassane Samba (Eds.), Artisans de la mer: Une histoire de la pêche maritime sénégalaise (pp. 90-96). Dakar: Rochette.

Mbaye, A. (2018), PhD ThesisPêche artisanale sénégalaise et gouvernance du changement climatique, thèse de doctorat unique. Paris: Muséum National d'Histoire Naturelle/ Sorbonne Université.

Mbaye, A. (2019). La pêche artisanale et le changement climatique au Sénégal entre savoirs du pêcheur et mesures politiques (pp. 0-356). Paris: Harmatan.

Mbaye, A., Cormier-Salem, M. C., \& Fall, A. S. (2017). Delta du Saloum: Nouvelle gouvernance des ressources à travers un retour aux savoirs empiriques. Sciences participatives, gouvernance des patrimoines et territoires des deltas: Actes du colloque international du Laboratoire mixte international " patrimoines et territoires de l'Eau" du 11 au 14 mai 2016 à l'Université gaston berger de Saint-louis du Sénégal. L'Harmattan, 199-213.

Mboa Nkoudou, T. H. (2015). Stratégies de valorisation des savoirs locaux africains: Questions et enjeux liés à l'usage du numérique au cameroun. Éthique publique, 17 (2). https://doi.org/10.4000/ethiquepublique.2343

Mbonda, E.-M., \& Rondeau, D. (2015). La contribution des savoirs locaux à l'éthique, au politique et au droit. Presses de l'Université Laval, ISBN 978-2-7637-2685-4.

McCave, I. N. (1978). Grain-size trends and transport along beaches: Example from eastern England. Marine Geology, 28(1-2), M43-M51. https://doi.org/10.1016/ 0025-3227(78)90092-0

Medeiros, M. C., Barboza, R. R. D., Martel, G., \& Mourão, J.d. S. (2018). Combining local Fishers' and scientific ecological knowledge: Implications for comanagement. Ocean \& Coastal Management, 158, 1-10. https://doi.org/10.1016/j. ocecoaman.2018.03.014

MPEM / Direction des pêches Maritimes (DPM). (2018). Résultats généraux des pêches maritimes. Rapport statistique (p. 126). MPEM.

Nakashima, D., \& Roué, M. (2002). Indigenous knowledge, peoples and sustainable practice. In P. Timmerman (Ed.), Social and economic dimensions of global environmental change, Encyclopedia of Global Environmental Change (Vol. 5, pp. 314-324). Chichester, New York: JohnWiley and Sons Ltd.

Negura, L. (2006). L'analyse de contenu dans l'étude des représentations sociales, Sociologie, Théories et recherches. OpenEdition. https://doi.org/10.4000/sociologies.993.
Nursey-Bray, M. J., Vince, J., Scott, M., Haward, M., O’Toole, K., \& Smith, T. (2016). Science into policy? Discourse, coastal management and knowledge. Environmental Science \& Policy. https://doi.org/10.1016/j.envsci.2013.10.010, 0.

Prospero, J. M., \& Carlson, T. (1970). Carlson Saharan Air Outbreaks Over the Tropical North Atlantic January 1980. Pure and Applied Geophysics, 119(3), 677-691. https:// doi.org/10.1007/BF00878167

Remolà, A. O., \& Gudmundsson, A. (2018), FAO Fisheries and Aquaculture Circular No. 1153: 1153. Global review of safety at sea in the fisheries sector (pp. 0-134). Rome: Food and Agriculture Organization of the United Nations. https://www.fao.org/3/i9 185en/19185EN.pdf.

Richardson, L. F. (1926). Atmospheric diffusion shown on a distance-neighbour graph. Proc. R. Soc. Lond. A., 110, 709-737. https://doi.org/10.1098/rspa.1926.0043

Rondeau, D. (2009). Quelle place pour les savoirs locaux dans la cité globale?. La philosophie et les interprétations de la mondialisation en Afrique (pp. 289-295). Paris: L'Harmattan.

Rondeau, D. (2016). La place des savoirs locaux (endogènes) dans la cité globale. Essai de justification. In Justice cognitive, libre accès et savoirs locaux. Pour une science ouverte juste, au service du développement local durable, sous la direction de Florence Piron, Samuel Regulus et Marie Sophie Dibounje Madiba. Québec, Éditions science et bien commun https://scienceetbiencommun.pressbooks.pub/justicecognitive1.

Roué, M., Césard, N., Adou Yao, Y. C., \& Oteng-Yeboah, A. (Eds.). (2017). Knowing our Lands and Resources: Indigenous and local knowledge of biodiversity and ecosystem services in Africa. Paris: Unesco.

Ruddle, K. (1994). Un guide de la littérature sur la gestion traditionnelle de la pêche communautaire dans les tropiques de l'Asie-Pacifique. Circulaire de la FAO sur les pêches. Rome: FAO. No. 869.

Ruggiero, Peter, Holman, R. A., \& Beach, R. A. (2004). Wave run-up on a high-energy dissipative beach. Journal of Geophysical Research, 109(C6). https://doi.org/ 10.1029/2003JC002160

Satia, B. P., \& Horemans, B. W. (1995). Les approches participatives et l'aménagement Traditionnels des Pêches en Afrique de l'Ouest. Rapport technique $N^{\circ}$ 70, Programme pour le Développement Intégré des Pêches Artisanales en Afrique de l'Ouest. DIPA/WP.

Seijger, C., Dewulf, G., Otter, H., \& Van Tatenhove, J. (2013). Understanding interactive knowledge development in coastal projects. Environmental Science \& Policy. https:// doi.org/10.1016/j.envsci.2013.02.007, 0.

Sène, A. (1985). Les transformations sociales dans la pêche maritime piroguière: conditions de travail et modes de vie des pêcheurs de Guet-Ndar de Saint- Louis du Sénégal. Toulouse: Université de Toulouse Le Mirail. pp. 0-706. Thèse de doctorat, UER sciences sociales.

Smit, B., Burton, I., Klein, R. J., et al. (2000). An Anatomy of Adaptation to Climate Change and Variability. Climatic Change, 45, 223-251. https://doi.org/10.1023/A: 1005661622966

Tengö, M., Hill, R., Malmer, P., Raymond, C. M., Spierenburg, M., \& Danielsen, F. (2017). Weaving knowledge systems in IPBES, CBD and beyond-lessons learned for sustainability. Current Opinion in Environmental Sustainability, 26, 17-25. https://doi. $\mathrm{org} / 10.1016 / \mathrm{j}$. cosust.2016.12.005. https://www.sciencedirect.com/science/artic le/pii/S1877343517300039

Thomas, J. (2018). Reconnaissance politique, savoirs professionnels, Expérimentation, légitimation, réflexivité et organisation d'un groupe d'agriculteurs autour des connaissances professionnelles. Revue d'anthropologie des connaissances, 12(2), 229-257. https://www.cairn.info/revue-anthropologie-des-connaissances-2018-2page-229.htm.

UNESCO. (2003). Les systèmes de savoirs locaux et autochtones (LINKS). New-York: UNESCO. https://fr.unesco.org/links.

USAID. (2018). Capitalisation de la démarche du projet USAID/COMFISH en matière d'élaboration et de mise en cuvre des outils de cogestion des ressources halieutiques au Sénégal (pp. 0-61). Dakar: USaid. https://pdf.usaid.gov/pdf_docs/PA00TR6F.pdf.

Van Chi Bonnardel, R. (1985). Vitalité de la petite pêche tropicale, pêcheurs de Saint-Louis du Sénégal, Paris, CNRS, Mémoires et documents de géographie, Nouvelles Collection.

Varela, F. J. (2004). Quel savoir pour l'éthique?, 171. Action, sagesse et cognition, Collection: La Découverte Poche / Sciences humaines et sociales (pp. 1-126). La decouverte.

Warren, D. M. (1993). Putting local knowledge to good use. Internationnal Agricultural Development, 13(4), 8-10.

World Intellectual Property Organization (WIPO)/CIPI. (2002). Savoirs traditionnels terminologie et définitions (on line). Doc. WIPO/GRTKF/IC/3/9 http://www.wipo.int/ $\mathrm{edocs} / \mathrm{mdocs} / \mathrm{tk} / \mathrm{fr} /$ wipo_grtkf_ic_3/wipo_grtkf_ic_3_9.pdf. 